\title{
Correction to: Estimating the urban environmental impact of gasoline-ethanol blended fuels in a passenger vehicle engine
}

\section{Gilson Tristão Duarte ${ }^{1} \cdot$ Irenilza de Alencar Nääs ${ }^{1}$ (D) $\cdot$ Nilsa Duarte da Silva Lima ${ }^{1}$}

Published online: 23 April 2021

(C) Springer-Verlag GmbH Germany, part of Springer Nature 2021

\section{Correction to: Environmental Science and Pollution Research} https://doi.org/10.1007/s11356-021-13432-5

The correct images of Figs. 3 and 5 are presented in this paper.

The original article has been corrected.

Fig. 3 The random tree for classifying the ethanol and gasoline blend's environmental impact using the variables ethanol blend and engine rotation

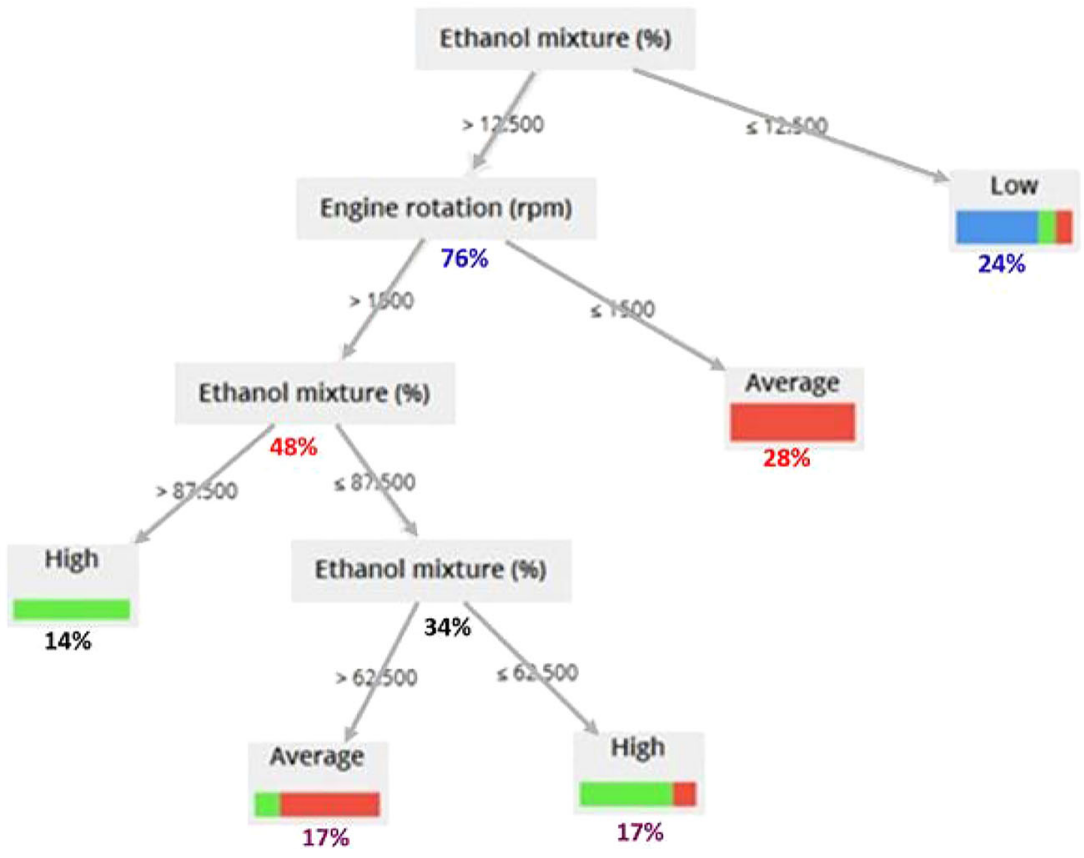

The online version of the original article can be found at https://doi.org/10. 1007/s11356-021-13432-5

Irenilza de Alencar Nääs

irenilza.naas@docente.unip.br

Nilsa Duarte da Silva Lima nilsasilvalima@gmail.com

Gilson Tristão Duarte

gilson.duarte@docente.unip.br

1 Graduate Program in Production Engineering, Paulista University, Rua Dr. Bacelar 1212- Vila Clementino, Sao Paulo, SP CEP 04043-200, Brazil 
Fig. 5 The random tree for classifying the ethanol and gasoline mixture's environmental impact using $\lambda$, ethanol blend, engine rotation, and the air-fuel ratio

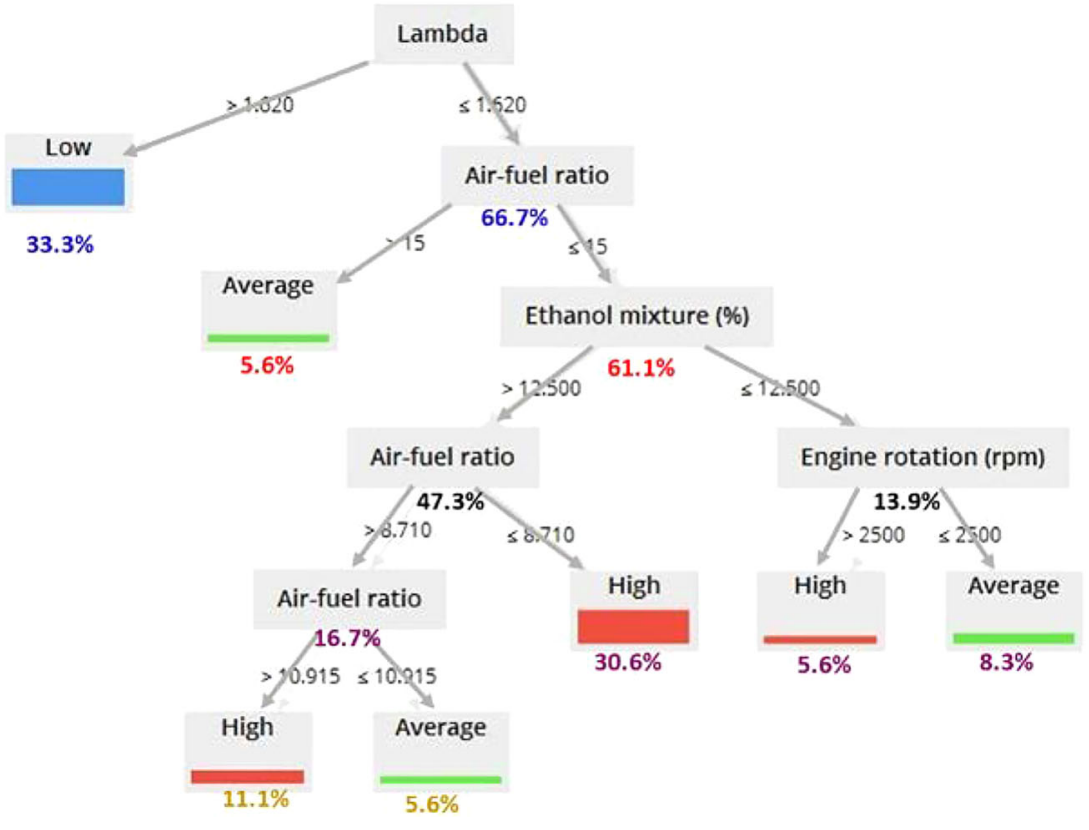

Publisher's note Springer Nature remains neutral with regard to jurisdictional claims in published maps and institutional affiliations. 